\title{
Canadian-style medical education in China
}

$\mathrm{F}$ or years, Canadian medical schools have been opening branch campuses in places such as Prince George, British Columbia, and Windsor, Ontario. In October, the University of Ottawa medical school went one better by opening a campus on the other side of the world.

Located in Shanghai - China's largest city, with more than 24 million residents - the new campus was created thanks to a program announced last year. It took solid form on Oct. 17, when 56 Chinese students at the Ottawa-Shanghai Joint School of Medicine participated in a white coat ceremony to mark the launch of their medical careers.

The new school exists because of a unique collaborative relationship between the University of Ottawa and the Shanghai Jiao Tong University School of Medicine. Roughly four years in the making, it marks the first time a Chinese medical school has adopted a North American training program.

Dr. Jacques Bradwejn, dean of medicine at the University of Ottawa, will also serve as dean at the joint school. It exists, at least in part, because of a fortunate convergence between the University of Ottawa's strategic plan, which calls for more international outreach, and China's decision to pursue health care reform, particularly in primary care.

Dr. Li Shao, vice-dean of the joint school, says international outreach is also one of its major goals. She thinks it will "expand the horizons" of Chinese students. "They will not only receive medical knowledge but knowledge about professionalism, self-reflective learning and life-long learning, skills they will need after graduation."

The program will also open new lines of communication between Chinese students and Canadian students and professors. "If possible," said Shao, "we'd like our students to spend two summers in Canada and have some clinical rotations and electives in Ottawa."

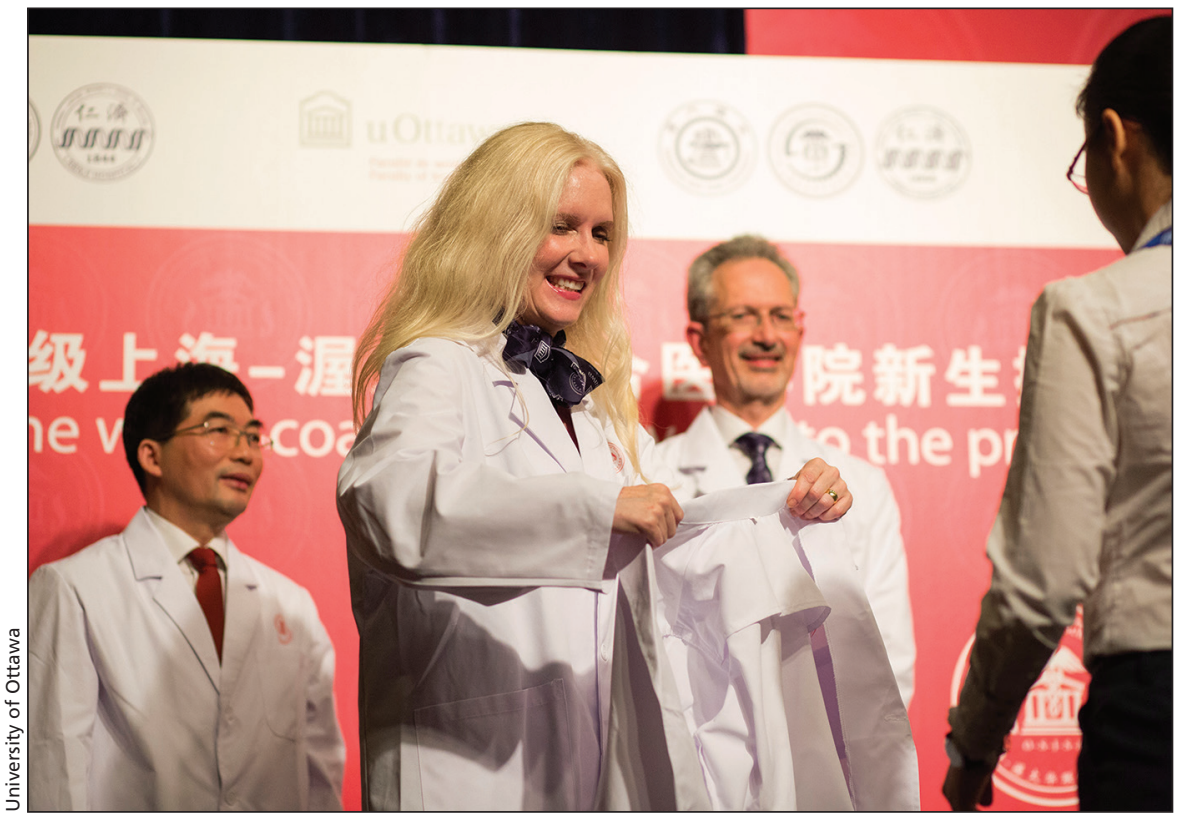

Leaders from the Shanghai Jiao Tong University School of Medicine and the University of Ottawa's medical school present white coats to the first $\mathbf{5 6}$ students attending the new Ottawa-Shanghai Joint School of Medicine.

The students, selected from all parts of China, will be taught primarily in English. They will take introductory courses during the first year, and then begin a four-year medical-degree program based on the University of Ottawa's training system. Staff in Ottawa and Shanghai will do the teaching and the focus will be on Canadian-style family medicine.

Shao said entry to the joint program is based largely on results from China's hyper-competitive national college entrance exam. She said there are "hundreds" of medical schools in China, including five in Shanghai, and the entry process is "very competitive."

Bradwejn said the joint program involves investments of \$1 million from both sides. "In 2013 we put $\$ 1$ million on the table, and they matched it in 15 seconds," he said. In the process, the University of Ottawa beat out competing bids from some Ivy League schools.

"One key reason we won is that we are there to invest, not to profit," he said. However, other factors were also in play. For instance, "it did not hurt" that a Canadian physician, Dr. Norman Bethune, is still revered for his work in China in the 1930s, or that Canada was the second nation to recognize the People's Republic of China.

Bradwejn said it also helped that the project had strong support from the university. "This is the start of a meaningful and historic partnership that will broaden our international reach," the University of Ottawa President Allan Rock said when the joint school was announced. "It will [let] Canadian and Chinese students . . . learn how medicine is practised in another culture."

It will also allow students to pursue additional training in China. This, in turn, will allow them to earn dual medical degrees - one in Canada and one in China - and to gain experience in global and population health and traditional Chinese medicine. "That is value added for our students," said Bradwejn.

Bradwejn, who currently visits Shanghai every three months, said the new school is using a "train-the-trainer" approach. The emphasis will be on 
family medicine because even though China has a "very sophisticated and super-specialized" tertiary care system, primary care has not developed at the same pace.

"China uses [general practitioners] the way we did 25 years ago," Bradwejn said. He believes the introduction of a more sophisticated approach will provide major benefits, particularly in areas such as health promotion. He said the Canadian proposal benefited because China, which is home to 1.35 billion people, is rolling out a new national strategy calling for better access to health care.

Part of Bradwejn's job in developing the new program was to promote the Canadian approach to family medicine. In doing so, he stressed that Canada has a robust primary care system that is a popular career choice for new graduates. At the University of Ottawa, for instance, more than half of the 2015 graduates $(51.8 \%)$ made family medicine their first residency choice.

A "Canadian-style family medicine clinic" that will be used to train students has already been built at the 2000-bed Renji Hospital in Shanghai, and it will serve as a pilot project for the development of a broader family medicine sector across China.

Bradwejn is positive about what the future holds: "Both sides are strongly committed to a long-term, substantial partnership." - Patrick Sullivan, Ottawa, Ont.

CMAJ 2016. DOI:10.1503/cmaj.109-5197 